\title{
Endothelial Nitric Oxide Synthase Gene Polymorphism and Periodontal Disease
}

\author{
Fernanda Gobbi Amorim¹, Maria Bernadete Depoli², Giovana Machado Souza Simões², \\ Bianca Prandi Campagnaro ${ }^{2}$, Clarissa Loureiro Tonini ${ }^{2}$, Iuri Drumond Louro ${ }^{1}$, \\ Jose Airton Arruda ${ }^{3}$, Elisardo Corral Vasquez ${ }^{2}$, Silvana dos Santos Meyrelles ${ }^{1,2}$
}

${ }^{1}$ Biotechnology Graduate Program, Health Sciences Center, Federal University of Espirito Santo, Vitoria, Brazil; ${ }^{2}$ Department of Physiological Sciences, Health Sciences Center, Federal University of Espirito Santo, Vitoria, Brazil; ${ }^{3}$ Intercath-Meridional Hospital, Cariacica, Brazil.

Email: meyrelle.vix@terra.com.br

Received April 20 $0^{\text {th }}, 2012$; revised May 23 ${ }^{\text {rd }}, 2012$; accepted June $1^{\text {st }}, 2012$

\begin{abstract}
The endothelial isoform of nitric oxide synthase (eNOS) is responsible for the physiological production of NO in endothelial cells and platelets. There is evidence that the G894T polymorphism of the eNOS gene is associated with this enzyme's basal activity and NO production, which could contribute to the pathogenesis of periodontal diseases (PD). Therefore, this study was designed to investigate the role of G894T polymorphism in the eNOS gene as a predisposing factor to periodontal disease. In this study we investigated the association of this polymorphism with PD in an admixture population $(\mathrm{N}=119)$ separated into three groups: Healthy control, Moderate and Severe PD, without statistical differences among them for risk factors for PD, such as age, gender and smoking status. We observed that the GG genotype was associated with the progression of PD as indicated by an increase in frequency of approximately $18 \%$ in the Moderate and $26 \%$ in the Severe groups compared to the Healthy control group $(\mathrm{p}=0.0302)$. This finding indicates that patients carrying the GG genotype have a greater chance of developing PD compared with those carrying the T allele, and it reinforces the notion that genetic factors contribute to the development and aggravation of PD.
\end{abstract}

Keywords: eNOS; Polymorphism; Periodontal Disease

\section{Introduction}

Periodontitis is a chronic, tissue-destructive inflammatory state and multifactorial disease initiated and modulated by microbial and other environmental factors. Despite the impact of these external elements, there are convincing data indicating that genetic factors may play a significant role in the risk of periodontal diseases (PD) [1].

Nitric oxide (NO), which is a highly reactive free radical, is implicated in the pathogenesis of various diseases due to its role as a modulator of immunity [2]. NO is formed by the oxidation of L-arginine through the activation of three different nitric oxide synthase (NOS) isoforms, and the endothelial isoform (eNOS) is responsible for the physiological production of $\mathrm{NO}$ in endothelial cells and platelets [3]. eNOS-mediated NO production is also involved in critical processes relevant to periodontal disease pathogenesis, which include the inhibition of cyclooxygenase, regulation of osteoblast activity, prevention of leukocyte adhesion, release of superoxide anions from leukocytes, and suppression of T-cell proliferation
$[4,5]$; therefore, eNOS may be involved in the pathogenesis of periodontal diseases.

Gene polymorphisms, which are found in the eNOS gene, may cause significant changes in function by altering the levels or activities of specific proteins. In this case, a single base exchange ( $894 \mathrm{G}>\mathrm{T}$ ) in exon 7 of the eNOS gene results in a Glu/Asp amino acid substitution at residue 298 of the encoded protein. This substitution could result in reduced enzyme activity and basal NO production, which is possibly due to increased susceptibility to proteolytic cleavage [6]. Moreover, the polymorphism G894T of eNOS gene could be a potential genetic factor for association with periodontal disease. Therefore, this study was designed to investigate the role of the G894T polymorphism in the eNOS gene as a predisposing factor to $\mathrm{PD}$.

\section{Materials and Methods}

\subsection{Subject Population}

A total of 119 patients, admixtured (mulatto), of both genders, and averaging $52 \pm 10$ years old, were admitted 
to the Intercath-Meridional Hospital (Cariacica, ES, Brazil) and University Hospital Antonio Cassiano de Moraes (Vitoria, ES, Brazil) for periodontal evaluation. The patients were divided into three groups: patients without periodontal disease (Healthy Control Group, $\mathrm{N}=31$ ) and patients with diagnosis of moderate (Moderate Group, $\mathrm{N}$ $=53$ ) or severe (Severe Group, $\mathrm{N}=35$ ) PD. Patients that reported previous periodontal treatment within six months, that had less than six dental elements, that required medication prior to dental treatment, or that contained an immunological, acute or chronic inflammatory or infectious disease were excluded. The human research ethics committee of the Biomedical Center of the Federal University of Espirito Santo (FR-056981), Brazil, previously approved the study protocol. Written and informed consent was obtained from all patients.

\subsection{Clinical Data}

All patients provided information about periodontal diseases risk factors such as age, gender or smoking status. Patients were defined as smokers if they were currently or previously (less than one year ago) had been addicted to tobacco smoking. Periodontal disease was defined according to the severity of periodontitis by measuring the probing depth and attachment level obtained at six sites around each tooth present, and each patient was classified as being Healthy (no signs of PD or sites with probing depth $<3 \mathrm{~mm}$ ), with Moderate periodontitis (attachment loss of $>3$ to $<6 \mathrm{~mm}$ ) or with Severe periodontitis (attachment loss $>6 \mathrm{~mm}$ ).

\subsection{Genetic Analysis}

eNOS polymorphism was analyzed after genomic DNA extraction from peripheral blood leukocytes using the phenol-chloroform method. The G894T (rs1799983) polymorphism was analyzed by polymerase chain reaction (PCR) and restriction fragment length polymorphism analysis. PCR was performed using primers: 5'-TCC CTG AGG AGG GCA TGA GGC T-3' (sense) and 5'-TGA GGG TCA CAC AGG TTC CT-3' (antisense) (Life Technologies do Brazil Ltda., Invitrogen) to amplify the gene promoter region. DNA $(0.5 \mu \mathrm{g})$ was amplified using 2 U of Taq DNA polymerase (Life Technologies do Brazil Ltda., Invitrogen), $0.2 \mathrm{mM}$ of each dNTP, $0.2 \mu \mathrm{M}$ of each primer and $1.5 \mathrm{mM} \mathrm{MgCl}_{2}$ in a final volume of $30 \mu \mathrm{L}$. The amplification reaction was carried out by alternating 35 cycles of denaturing at $95^{\circ} \mathrm{C}(1$ min), annealing at $59^{\circ} \mathrm{C}(1 \mathrm{~min})$ and extension at $72^{\circ} \mathrm{C}(1$ min) using a DNA thermal cycler (Eppendorf, Sao Paulo, Brazil). The resulting 457-bp amplification product was incubated at $37^{\circ} \mathrm{C}$ for at least 3 hours with $2 \mathrm{U}$ of the restriction enzyme BanII (Uniscience, Sao Paulo, Brazil) and the amplified fragments were digested into smaller fragments (137 and $320 \mathrm{bp}$ ). The BanII restriction site is lost in the case of a $\mathrm{G}$ to $\mathrm{T}$ substitution at position 894 of the eNOS gene. Finally, the BanII treated fragments were separated on an $8 \%$ polyacrylamide gel stained with silver nitrate.

\subsection{Statistical Analysis}

Quantitative variables are presented as mean \pm SD and qualitative variables as percentages. To assess independent relationships between variables, one-way ANOVA (age) and X2 tests (gender and smoking habits) were performed. To assess the influence of genotypes on PD, a $\mathrm{X} 2$ test for trends was used. Statistical analysis was carried out with the GraphPad Prism 5.0 software. A p-value $\leq 0.05$ was considered as significant.

\section{Results}

Clinical characteristics and the prevalence of PD risk factors of the groups of patients are shown in Table 1. The data show no statistical differences between groups for age, gender and smoking habits.

The genotype and allele frequencies of the G894T eNOS polymorphism for each group are shown in Table 2. Genotype frequency was consistent with that predicted by the Hardy-Weinberg equilibrium in all groups of patients. A significant difference in genotype frequency was observed between groups $(p=0.0302)$. The homozygote genotype (GG) was associated with the severity of PD, with an increase of $18 \%$ in the frequency in the Moderate group and $26 \%$ in the Severe group compared with the Healthy Control group. The opposite was observed with the genotypes containing the polymorphic T allele (TG + TT): the frequency was higher in the Healthy Control group compared to the Moderate group $(-18 \%)$ and to the Severe group $(-26 \%)(p=0.0302)$. The $\mathrm{G}$ and $\mathrm{T}$ allele frequencies showed only a tendency toward the same results that were observed with genotype distributions.

\section{Discussion}

The pathophysiology of periodontitis, like other complex diseases, is characterized by various biological pathways leading to the same clinical phenomena. Multiple genes and their polymorphisms may all have a small overall contribution and relative risk to disease susceptibility and severity [1]. In the present study we intended to evaluate the contribution of the G894T polymorphism of the eNOS gene to PD in groups of Healthy Control, Moderate and Severe PD subjects. Our analysis of the G894T eNOS polymorphism shows that the GG genotype seems to be linked to the severity of PD.

Risk factors, such as aging, gender, and environmental factors, such as smoking, stress, and pathogenic bacteria, along with genetic factors, are involved in the pathogenesis 
Table 1. Clinical characteristics for each group.

\begin{tabular}{|c|c|c|c|c|}
\hline \multirow[b]{2}{*}{ Parameters } & \multicolumn{3}{|c|}{ Patients Tested for Periodontitis } & \multirow[b]{2}{*}{$P$ Value ${ }^{*}$} \\
\hline & $\begin{array}{l}\text { Healthy Control } \\
(\mathrm{N}=31)\end{array}$ & $\begin{array}{l}\text { Moderate } \\
(\mathrm{N}=53)\end{array}$ & $\begin{array}{c}\text { Severe } \\
(N=35)\end{array}$ & \\
\hline $\begin{array}{l}\text { Age (years), } \\
\text { mean } \pm \text { SD }\end{array}$ & $50 \pm 12$ & $53 \pm 9$ & $52 \pm 9$ & 0.1947 \\
\hline \multicolumn{5}{|l|}{ Gender } \\
\hline Female, \% (N) & $48(15)$ & $26(14)$ & $26(9)$ & 0.0733 \\
\hline Male, $\%(\mathrm{~N})$ & $52(16)$ & $74(39)$ & $74(26)$ & \\
\hline Smoker, \% (N) & $39(12)$ & $41(22)$ & $37(13)$ & 0.9144 \\
\hline
\end{tabular}

*One-way ANOVA (age) and $\mathrm{X}^{2}$ (gender and smoking).

Table 2. Genotype and allele frequencies of eNOS gene polymorphism of each group.

\begin{tabular}{|c|c|c|c|c|c|}
\hline \multirow{2}{*}{$\begin{array}{l}\text { Frequency } \\
(\%)\end{array}$} & \multicolumn{3}{|c|}{$\begin{array}{l}\text { Patients Tested for } \\
\text { Periodontitis }\end{array}$} & \multirow{2}{*}{$\mathrm{X}^{2}$} & \multirow{2}{*}{$P$ Value } \\
\hline & $\begin{array}{l}\text { Healthy Control } \\
(\mathrm{N}=31)\end{array}$ & $\begin{array}{l}\text { Moderate } \\
(\mathrm{N}=53)\end{array}$ & $\begin{array}{c}\text { Severe } \\
(N=35)\end{array}$ & & \\
\hline \multicolumn{6}{|l|}{ Genotype } \\
\hline GG & 42 & 60 & 68 & 4.696 & $0.0302^{*}$ \\
\hline $\mathrm{TG}+\mathrm{TT}$ & 58 & 40 & 32 & & \\
\hline \multicolumn{6}{|l|}{ Allele } \\
\hline G & 71 & 77 & 81 & 2.048 & 0.3591 \\
\hline $\mathrm{T}$ & 29 & 23 & 19 & & \\
\hline
\end{tabular}

${ }^{*} p \leq 0.05$ ( $\mathrm{X}^{2}$ for trends).

of periodontitis [7]. Importantly, we ruled out the possible influence of risk factors for PD, such as aging, gender and smoking habits, on the results from the polymerphism analysis because these parameters were of similar proportion among the 3 groups of patients. This reinforces the contribution of genetic factors to the etiology of the PD [1].

There are evidences that eNOS may be involved in the pathogenesis of PD $[4,5]$, but the gene polymorphisms of this enzyme is not yet well established. The G894T polymorphism is the only coding region variation among the several identified polymorphisms of the eNOS gene and has been suggested to be a non-silent variant $[6,8]$. This substitution has been reported to exert a functional effect on the eNOS protein and is associated with altered NO synthesis and bioavailability, indicating that subjects with the TT genotype may be more susceptible to endothelial dysfunction [9]. Also, the susceptibility associated with this substitution may lead to exaggerated inflammation and periodontal tissue destruction because eNOSmediated NO production is suggested to be tissue protecttive and possesses anti-inflammatory features [2]. The involvement of the G894T polymorphism of the eNOS gene in PD was previously evaluated in two studies in a Turkish population $[2,10]$. The authors observed an increase in this polymorphism in patients with PD compared with those without the disease and observed a significant association with the severity of PD and presence of gingivitis. However, in our study with an admixtured Brazilian population, we evaluated this polymorphism in accordance with the severity of the PD and observed that the GG genotype seems to be associated with the progression of PD $(18 \%$ in the Moderate and $26 \%$ in the Severe groups compared to the Healthy Control group). The discrepancy in the results among these three studies seems to be due to differences in the patient's race.

Metzger et al. [11,12] evaluated the effects of the described polymorphisms of eNOS (T-786C in the promoter region, b/a in intron 4, and G894T in the exon 7) related to plasma levels of nitrite metabolites and found that a specific eNOS haplotype, which includes the $\mathrm{C}, 4$ $\mathrm{b}$, and $\mathrm{G}$ alleles, is associated with lower circulating NO levels $[11,12]$. Moreover, it has been shown that approximately $70 \%$ of plasma nitrite is derived from NOS activity in the endothelium [13]. Thus, the above studies support our findings that show that patients with the GG genotype of the G894T polymorphism of the eNOS gene have a greater risk of developing PD.

In conclusion, this study is the first to evaluate the involvement of the eNOS polymorphism in PD for a Brazilian population. We observed a higher incidence of the GG genotype of G894T polymorphism of eNOS gene in patients with moderate to severe PD compared to healthy control individuals. This finding indicates that patients carrying the GG genotype have a greater chance of developing $\mathrm{PD}$ compared with those carrying the $\mathrm{T}$ allele, reinforcing the contribution of genetic factors to the development and aggravation of $\mathrm{PD}$.

\section{Acknowledgements}

This study was supported by the National Council for the Development of Science and Technology $(\mathrm{CNPq})$ and the State Agency for the Development of Science and Technology (FAPES).

\section{REFERENCES}

[1] M. L. Laine, B. G. Loos and W. Crielaard, "Gene Polymorphisms in chronic Periodontitis," International Journal of Dentistry, Vol. 2010, 2010, Article ID 324719, 22 p. doi:10.1155/2010/324719

[2] A. Berdeli, A. Gürkan, G. Emingil, G. Atilla and T. Köse, "Endothelial Nitric Oxide Synthase Glu298Asp Gene Polymorphism in Periodontal Diseases," Journal of Periodontology, Vol. 77, No. 8, 2006, pp. 1348-1354. doi:10.1902/jop.2006.050320

[3] J. E. Tanus-Santos, M. Desai, L. R. Deak, J. C. Pezzullo, D. R. Abernethy, D. A. Flockhart and J. E. Freedman, "Effects of Endothelial Nitric Oxide Synthase Gene Polymorphisms on Platelet Function, Nitric Oxide Release, and Interactions with Estradiol," Pharmacogenetics, Vol. 12, No. 5, 2000, pp. 407-413. doi:10.1097/00008571-200207000-00008 
[4] S. B. Abramson, A. R. Amin, R. M. Clancy and M. Attur, "The Role of Nitric Oxide in Tissue Destruction," Best Practice \& Research Clinical Rheumatology, Vol. 15, No. 5, 2001, pp. 1831-845. doi:10.1053/berh.2001.0196

[5] R. J. van't Hof and S. H. Ralston, "Nitric Oxide and Bone," Immunology, Vol. 103, No. 3, 2001, pp. 255-261. doi:10.1046/j.1365-2567.2001.01261.x

[6] M. Tesauro, W. C. Thompson, P. Rogliani, L. Qi, P. P. Chaudhary and J. Moss, "Intracellular Processing of Endothelial Nitric Oxide Synthase Isoforms Associated with Differences in Severity of Cardiopulmonary Diseases: Cleavage of Proteins with Aspartate vs. Glutamate at Position 298," Proceedings of the National Academy of Sciences USA, Vol. 97, 2000, pp. 2832-2835. doi:10.1073/pnas.97.6.2832

[7] L. N. Borrell and P. N. Papapanou, "Analytical Epidemiology of Periodontitis," Journal of Clinical Periodontology, Vol. 6, 2005, pp. 132-158. doi:10.1111/j.1600-051X.2005.00799.x

[8] J. P. Casas, L. EBautista, S. E. Humphries and A. D. Hingorani, "Endothelial Nitric Oxide Synthase Genotype and Ischemic Heart Disease: Meta-Analysis of 26 Studies Involving 23028 Subjects," Circulation, Vol. 109, 2004, pp. $1359-1365$. doi:10.1161/01.CIR.0000121357.76910.A3

[9] C. P. Leeson, A. D. Hingorani, M. J. Mullen, N. Jeerooburkhan, M. Kattenhorn, T. J. Cole, D. P. Muller, A. Lucas, S. E. Humphries and J. E. Deanfield, "Glu298Asp Endothelial Nitric Oxide Synthase Gene Polymor- phism Interacts with Environmental and Dietary Factors to Influence Endothelial Function," Circulation Research, Vol. 90, 2002, pp. 1153-1158. doi:10.1161/01.RES.0000020562.07492.D4

[10] K. Erciyas, S. Pehlivan, T. Sever, M. Igci, M. Pehlivan, A. Arslan and R. Orbak. "Endothelial Nitric Oxide Synthase Gene Polymorphisms Associated with Periodontal Diseases in Turkish Adults," African Journal of Biotechnology, Vol. 9, No. 21, 2010, pp. 3042-3047.

[11] I. F. Metzger, D. C. Souza-Costa, A. S. Marroni, S. Nagassaki, Z. Desta, D. A. Flockhart and J. E. Tanus-Santos, "Endothelial Nitric Oxide Synthase Gene Haplotypes Associated with Circulating Concentrations of Nitric Oxide Products in Healthy Men," Pharmacogenetics Genomics, Vol. 15, No. 8, 2005, pp. 565-570. doi:10.1097/01.fpc.0000167328.85163.44

[12] I. F. Metzger, J. T. Sertório and J. E. Tanus-Santos, "Modulation of Nitric Oxide Formation by Endothelial Nitric Oxide Synthase Gene Haplotype," Free Radical Biology and Medicine, Vol. 43, No. 6, 2007, pp. 987-992. doi:10.1016/j.freeradbiomed.2007.06.012

[13] P. Kleinbongard, A. Dejam, T. Lauer, T. Rassaf, A Schindler, O. Picker, T. Scheeren, A. Gödecke, J. Schrader, R. Schulz, G. Heusch, G. A. Schaub, N. S. Bryan, M. Feelisch and M. Kelm, "Plasma Nitrite Reflects Constitutive Nitric Oxide Synthase Activity in Mammals," Free Radical Biology and Medicine, Vol. 35, No. 7, 2003, pp. 790-796. doi:10.1016/S0891-5849(03)00406-4 